\title{
Muslim NGOs and the Quest for Environmental Sustainability in the Context of the Sustainable Development Goals
}

\author{
Draft Version \\ Authored by Jens Koehrsen \\ Centre for Religion, Economy and Politics; University of Basel
}

Article to be published in:

Heuser, Andreas; Koehrsen, Jens (ed.) (2020) Does Religion make a Difference?

Religious NGOs in International Development Work, Zürich/Baden-Baden:

Nomos, p. 327-348.

https://doi.org/10.5771/9783748907633-327 


\begin{abstract}
The contribution addresses the role of Muslim NGOs in environmental sustainability. Reviewing empirical studies about this topic, it discusses the potentials and challenges of Muslim NGOs to promote environmental sustainability. Crucial resources for this endeavour are the environmental teachings of Islam and the grassroots reach of these organisations. Religious scholars often stress the rich scriptural resources of Islam for tackling environmental issues. Moreover, unlike other (secular) NGOs, Muslim NGOs can reach local populations in Muslim majority countries where they usually enjoy high credibility. Existing studies mention numerous initiatives of Muslim NGOs to advance environmental sustainability, among them radio campaigns, tree-planting activities, environmental awareness and education programs, the dissemination of environmental knowledge through religious leaders, the issuing of fatwas to declare logging illegal, and the implementation of sustainable resource management in Muslim organisations. Nevertheless, there are also important challenges to this environmental engagement. The Islamic environmental ethics that environmentally concerned Islamic scholars and activists highlight reflect their own perceptions of Islam, but not necessarily that of the broader Muslim population. As such, at the grassroots level, there is often low acceptance for Islamic environmental initiatives that have, consequently, little impact. In total, while bearing specific potentials for reaching wider populations through its grass-roots reach, Muslim environmentalism remains often limited to the environmental concerned Muslim organisations and activists.
\end{abstract}

\title{
1 Introduction
}

Religious NGOs have become a bearer of hope in the field of development. However, it is not clear how these actors relate to the newly established Sustainable Development Goals (SDGs). The new emphasis on environmental sustainability in the SDGs, combined with strong academic claims about the importance of religion for tackling environmental problems, raise the question of how religious NGOs relate to environmental sustainability and in what way they can engage in it. This contribution addresses the role of Muslim NGOs. Reviewing different contributions to the subject, it provides an overview of the potentials and challenges of these organisations in the struggle for environmental sustainability. It thereby addresses the question in what way Muslim NGOs can make a difference in transformation processes towards environmentally friendly societies. The article shows that studies about this subject frequently outline the environmental teachings of Islam and its grassroots reach as crucial resources. However, studies also indicate that the impact of Islamic environmental initiatives on broader Muslim populations remains unclear and that these initiatives may suffer from low acceptance at the grassroots level.

The remainder of this article is as follows: The second section addresses the debate about religion and ecology while the third section turns to the challenges of Muslim NGOs in the transnational development field. The fourth section portrays different studies about Muslim environmental activism. Based on these insights, the following section recapitulates the main observations and compares the resources as well as limitations of Muslim organisations in promoting environmental sustainability. The article ends with a conclusion summarizing the results and sketching potential avenues for research.

\section{Faith Based Development: Towards a "Green" Agenda?}

In the last decades, shared global development goals have been established by the United Nations such as the Millennium Development Goals (MDGs) and Sustainable Development Goals (SGDs). The 
SDGs have replaced the MDGs and shape international development work from 2015 until 2030. They consist of 17 major goals that cover different areas of development policy, ranging from poverty alleviation, economic inequality, health, education, peace building, infrastructures, to environmental sustainability. In comparison to the MDGs, the SDGs place a strong emphasis on the notion of

"sustainability" and particularly on environmental sustainability. While development concepts have originally stressed human well-being (e.g. economic wealth, health, education), the novel focus on environmental sustainability creates a new context for international development activities in which global and local environmental problems assume a rising importance. However, it is, so far, unclear how religious NGOs from different faith backgrounds will relate to the SDGs. Will their development concepts and activities reflect the novel emphasis on environmental sustainability? What resources can these organisations employ to promote environmental sustainability and what limitations do they face when tackling environmental sustainability?

The academic debate about religion and ecology highlights the potentials of religion for promoting environmental sustainability (Clugston and Holt 2012; Gottlieb 2008; Kimmins 1993; Rasmussen 2011; Rolston III 2006; Tucker 2006; Tucker 2008). Some scholar suggest an ongoing "greening" process among the world's faith traditions that renders the teachings of these traditions and the lifestyles of their followers more environmentally friendly (Kanagy and Willits 1993; Shibley and Wiggins 1997; White 1966; Taylor 2010). Studies about religion and ecology name different resources that allow religious organisations to contribute to render societies more environmentally friendly. Gardner (2003), for instance, suggests five religious assets for promoting environmental sustainability: worldview development (e.g. pro-environmental religious teachings), moral authority, numbers of followers that can reached, material resources, and community building (e.g. social bonds and trust in religious communities) (Gardner 2003). Other studies posit that religious organisations could use their public visibility for campaigning and lobbying, draw upon their material and organisational infrastructures to undertake transitions activities (e.g. energy efficiency measures in church buildings), and employ their networks and local reach to disseminate pro-environmental ethics (Koehrsen 2015; Koehrsen 2018). Contributions further show that religious organisations may use emotional campaigning for advocacy work and assume an mediation role in climate negotiations (Glaab 2017).

The aforementioned resources may enable religious organisations to contribute to societal transformations towards environmental sustainability. However, empirical research about religion and environmental change has particularly focused on Christian organisations, addressing their public involvement and their potential influence on environmental attitudes. This research has generated mixed results regarding the environmental impact of Christianity and rather tends to reject the hypothesis of a general "greening" process in Christianity (Taylor, van Wieren and Zaleha 2016). Against the backdrop of a Christian focus in research, we know, so far, little about how Muslim organisations seek to facilitate environmental sustainability and what difference they can make in the novel sustainable development agendas.

\section{Muslim NGOs}

In the last decades, an increasing number of Muslim NGOs have emerged (Petersen 2012a; Petersen 2012a:133-34; Petersen 2012b; and Peterson in this volume). This growth is related to a general increase in the number of NGOs and the rising solidarity between Muslims worldwide in the context of wars and disasters (e.g. famines in Africa, Soviet war in Afghanistan, civil war in Bosnia), facilitating 
the creation of Islamic aid organisations. By 2010, Petersen (Petersen 2012a:134) estimates the number of Muslim NGOs in the field of aid provision to be 400 out of 16,700 transnational NGOs, representing $2.4 \%$ of all transnational NGOs. The majority of these organisations come from the USA and Europe (particularly the UK).

Similar to other religious NGOs, Muslim NGOs are sometimes accused of proselytization and fundamentalism (Ahmed 2009; Kaag 2007; Petersen 2012a; Salih 2002). However, Muslim NGOs are diverse and show different orientations, varying in their tendencies for proselytization and fundamentalism (Petersen 2012b). Like other religious NGOs, Muslim NGOs are active in different fields such as humanitarian assistance in the context of natural disasters and famines, poverty alleviation, refugee support, education, health, finance, and business entrepreneurship (Ahmed 2009; Kaag 2007; Kirmani and Khan 2008; Petersen 2012b; Salih 2002)

In the context of the international "war on terror", some of these organisations have been accused of links to terror organisations and banned from Western countries (Petersen 2012a:135-36; Petersen 2012b:771-74). At the same time, Western policy makers and agencies have sought to strengthen their collaboration with Muslim NGOs to counteract Islamic radicalization processes. From the perspective of these agencies, Muslim NGOs become instruments of reaching local Muslim populations that are otherwise difficult to access (see also Cordier 2009):

"In this perspective, the religious identity of organisations is considered an instrument in the effective implementation of aid activities, primarily serving as a tool for communication with constituencies that may otherwise be unreachable." (Petersen 2012a:137)

Religion becomes a tool for reaching the otherwise "unreachable". Nevertheless, in the context of a "rigidly secular aid regime" (Palmer 2011:107), there is a preference for secular approaches and sometime distrust again Muslim NGOs among governments and mainstream development agencies. As such, on the one hand, the label "Islamic" can obstruct the development work, as secular governments and agencies will rather support Muslim NGOs that represent a "secular" Islam (Kirmani and Khan 2008). On the other hand, local constituencies in predominantly Muslim countries often demand for religion to be included in development activities (e.g. constructing a mosque in a refugee camp) (Palmer 2011). Withdrawing Islam from these activities may undermine the credibility of these organisations among Muslim leaders and local populations and imperil their ability to reach the otherwise "unreachable". Western-based, secular-oriented Muslim NGOs potentially face distrust at the grassroots level (Cordier 2009; Palmer 2011; Petersen 2012b:775). As such, Muslim NGOs are caught in a complex situation in which they have to handle the dissimilar expectations of the "secular" mainstream development field and their local constituencies.

Against the backdrop of this situation, Muslim NGOs undertake different positionings (Petersen 2012a; Petersen 2012b:773-74): some have turned towards mainstream development and collaborate with secular agencies while others have moved to the periphery of the mainstream development field or remain outside of this field. Regarding their religious identity, these organisations move in a spectrum between an all-encompassing Islam and an almost invisible Islam. Those organisations incorporating an almost invisible Islam are more adaptable with the mainstream development field. 


\section{Environmental Islam}

Studies about the environmental engagement of Muslim NGOs are rare. The following descriptions will outline some of the few existing studies about Islamic environmental engagement. Not all of the studies are focusing on Muslim NGOs, some of them address local ecological initiatives and attitudes towards environmental change. Nevertheless, the latter studies also provide insights into the potentials and problems of Muslim NGOs to promote sustainable Development.

\subsection{Islamic Environmental Teachings}

Studies about Islam and ecology tend to highlight the environmental teachings of Islam, drawing on the Qur'an (revelation of God) and the sunna (sayings and deeds of the prophet Muhammad) (Amri 2014:79-80; DeHanas 2009:143-44; Foltz 2000:64-66; Gilliat-Ray and Bryant 2011:288-89; Rice 2006:379-80; Saniotis 2012:156-58).

Islamic environmental teaching stresses that both humans and the environment are God's creation and that the universe exists in harmony and balance (tawhid). Forming part of God's creation, humans should respect nature. Moreover, as representatives of God in the world, humans assume active responsibility for caring for the environment: they are khalifah (stewards) that should act as caring protectors and maintain the balance of nature. Finally, humans will be held accountable for their actions towards the environment in the hereafter (akhirah).

These ideas outline the basis for an Islamic environmental ethic: scholars tend to stress that Islam has rich scriptural resources for addressing environmental problems (DeHanas 2009:143), that it places an emphasis on nature (Saniotis 2012:156-57), and that it "provides a comprehensive system for teaching the fundamental aspects of environmental care" (Mangunjaya and McKay 2012:289). Yet, rather than echoing Islam as it is lived by local populations, the environmental ethics reflect the readings and teachings of environmentally concerned Islamic scholars, clerics, activists, and organisations. These actors stress the potentials of Islam for tackling environmental problems and seek to disseminate an environmentally friendly ("green") Islam. The following studies explore their activities, outlining the strengths and problems of Islam for promoting environmental sustainability.

\subsection{Empirical Insights into Muslim Environmentalism}

The strong environmental potentials of Islam that scholars outline do not necessarily become manifest among broader Muslim populations and Muslim NGOs. A quantitative study shows that $15 \%$ of religious NGOs at the UN identify the environment of as one of their preferred fields of activity (Beinlich and Braungart 2019:33-35). However, only 6\% of the religious NGOs that describe the environment of as one of their preferred fields of activity are Muslim, compared to $58 \%$ Christian, $10 \%$ Buddhist and $10 \%$ Hindu, and $10 \%$ multireligious NGOs. As such, Muslim RNGOs seem to place a less prominent focus on environmental topics than religious NGOs from other faith backgrounds. Also scholars that underpin the strong environmental basis of Islam often acknowledge a relatively low environmental concern among broader Muslim populations (Amri 2014; DeHanas 2009; Gilliat-Ray and Bryant 2011; Saniotis 2012). Saniotis (2012) argues that the this discrepancy is related to the social history of Muslim majority countries. While Islam has strong environmental ethics that were originally employed in Muslim majority countries, the arrival of Western culture and its focus on materialism overshadowed these: 
"European colonial powers brought with them materialistic-orientated ideologies that focused on economic development and exploiting nature. This contributed to the deterioration of Islamic environmental ethics." (Saniotis 2012:168)

Muslim majority countries started to emphasize economic development that increasingly dwarfed Islamic environmental concern. Nevertheless, against the backdrop of environmental degradation and climate change, Saniotis (2012) stipulates that Muslims are rediscovering the environmental foundations and that Islamic environmentalism is gaining a new ground in these countries.

For instance, on the international level, the initiative "The Muslim 7 Year Action Plan on Climate Change" started in 2009. In 2010, the First International Conference on Muslim Action on Climate Change was held in Indonesia, setting out joint goals for the Muslim world. The goals include promoting a joint climate change policy in Muslim countries, the use of environmentally friendly technology, encouraging grassroots action, facilitating exchange of knowledge and best-practice across the Muslim world, and train religious leaders about climate change and disseminate environmental knowledge through Islamic boarding schools (Mangunjaya and McKay 2012:295-96; Saniotis 2012:162). However, it is not clear to what extent this global framework has influenced local action. The following case studies barely refer to such international agreements and initiatives. Only one case-study from Indonesia mentions this initiative (Mangunjaya and McKay 2012). For understanding the potentials and limitations of Muslim NGOs in environmental sustainability, it is important to have a closer look at the grassroots level. In the following, I review case studies from different socio-geographical contexts. The review starts with six case studies from different Global South countries followed by three case studies from the United Kingdom.

\subsubsection{Global South}

The Global South case studies reveal various resources for promoting environmental concern and environmentally friendly behaviour. Rice (2006) undertakes a quantitative study among high-school teachers and university students in Cairo (Egypt). She finds that talking about environmental issues relates to religion. Environmental activism remains marginal among the respondents, but when assuming shape, it also positively relates with their religiosity. As such, Rice (2006:387-88) suggests that the grassroots dissemination of Islamic environmental principles through imams would constitute a valuable channel to promote pro-environmental behaviour in Egypt.

"Governmental or nongovernmental groups promoting pro-environmental behaviors should focus their efforts at the grassroots level and find ways to use faith-based messages." (Rice 2006:388)

When transmitted via Friday prayers, faith-based environmental messages would gain an extensive reach in the wider population, given the strong religiosity of Egypt's population. Consequently, this study indicates the following strengths of Islamic engagement: the ability of Islam to trigger environmental concern, the effectiveness of faith-based messages in strongly religious contexts, and the extensive social reach of religious leaders.

A study from Sheikh (2006) about an environmental education project in Pakistan also highlights the social reach of Islamic leaders. The action-research project took place in Western Karakorum between 1996 and 2002. It aimed to improve knowledge about environmental conservation in this region with the support of local religious leaders. The high confidence that these leaders enjoy among the local population turned out to be a strong asset. It facilitates communication with local communities and 
the exchange of knowledge, maximizing local participation: the project gained access to local schools, mosques and rural communities while religious leaders themselves took active roles in spreading knowledge about humans' responsibilities in protecting the environment according to Islam. Thereby, the study points towards the social capital of religious leaders: their reputation among the population and their social networks. From this perspective, religious leaders constitute gatekeepers that can provide access to the wider population and facilitate the dissemination of environmental ethics.

Similarly, two case studies from Indonesia underpin the grassroots reach of Islamic leaders and organisations. Indonesia has the world's largest Muslim population. Deforestation is a crucial environmental problem in Indonesia while the general awareness about environmental problems is very low (Amri 2014; Mangunjaya and McKay 2012:292). The government, local authorities and NGOs seek to reduce logging. The Indonesian government undertakes top-down processes by, for instance, using legislation to declare local conservation areas. However, local populations often perceive these steps as unjust and endangering their economic well-being, as their incomes may depend on logging. Therefore, a greater inclusion of the grassroots level is necessary. According to Mangunjaya and McKay (2012:287-88), the involvement of local populations can be achieved by relying on Islamic teachings and Muslim networks. To illustrate their argument, they describe different activities that Islamic organisations and leaders have undertaken to spread pro-environmental attitudes and behaviour among local populations. One of these activities concerns the dissemination of information: Muslim scholars in Indonesia have engaged to create more awareness about ecological conservation within Islam by circulating their environmental teachings through books and workshops with Muslim teachers and clerics (Mangunjaya and McKay 2012:288-92). Moreover, many Pesantrens (Islamic boarding schools) in Indonesia have undertaken environmental programs. These include education and reforestation projects (Mangunjaya and McKay 2012:296). In some cases, projects involving religious teachers and local populations have even managed to create an Islamic Hima (environmental management zones) and Harim (inviolable sanctuaries) (Mangunjaya and McKay 2012:298-302). Finally, regional councils of religious scholars have issued Fatwas (non-binding legal opinions), declaring environmentally harmful logging and mining as haram. Moreover, a religious outreach programme, sending out 5,000 preachers to localities to stop illegal logging, has been initiated. However, it is unclear to what extent these undertakings have been effective to stop logging, as empirical research is missing (Mangunjaya and McKay 2012:302-03).

Amri (Amri 2014) studies the environmental activity of two particular Islamic organisations in Indonesia: Muhammadiyah and Nahdlatul Ulama. These are the two oldest and biggest Islamic civil society organisations in Indonesia (Amri 2014:78-79): Muhammadiyah is a vast organisation that involves 6,118 mosques, 5,519 schools, 172 universities, and 457 hospitals. Nahdlatul Ulama places a focus on education and covers around 17,000 boarding schools (Pesantrens). Both organisations seek to raise environmental awareness among Indonesian population and politics (Amri 2014:81). They have published public statements asking the government to act against environmental degradation and to stick to international climate goals. In order to reach local populations, they use teaching in mosques and Islamic teaching forums (Amri 2014:82-84). Here, clerics refer to relevant Qur'anic verses to explain, for instance, why it is important to keep the environment clean or refrain from logging. However, clerics often miss practical knowledge about climate change, which limits the dissemination of environmentally friendly behaviour. The engagement remains limited to small groups and might be perceived as elitist. As mentioned above, an important environmental topic in the context of Indonesia is illegal logging. Both organisations urge their followers to refrain from this practice. They reach out 
to local populations not only via teachings in mosques but also through Pesantrens. For instance, these local schools and their teachers invite communities to reflect about the long term consequences of cutting trees and to engage in reforestation projects (Amri 2014:85). Moreover, Nahdlatul Ulama seeks to provide alternative ways of generating income for the local populations by promoting stock farming and agricultural endeavours (Amri 2014:86). Muhammadiyah has initiated programs within its organisation to more sustainably manage its resources: it urged its hospitals, schools and universities to use recycled paper and reduce their consumption of water and energy. However, not all of their sub-organisations have implemented these calls. The reason for these problems in implementing a more sustainable resource management may lie in the historically stronger focus on education and poverty of Nahdlatul Ulama and Muhammadiyah where environmental activities receive less importance (Amri 2014:87). According to Amri (Amri 2014:82), these two organisations enjoy broad grassroots support in contrast to other environmentally concerned NGOs. Aside from the important grassroots reach, this study points towards the institutional resources of Islamic organisations (e.g. facilities and vast organisational infrastructures) and their power to lobby environmental positions towards political leaders. Furthermore, the study indicates some challenges: environmental concern and engagement remain small and will not always reach the grassroots level, as environmental goals compete with other, more prominent goals (e.g. education, poverty eradication).

Another limitation is that religious worldviews, even when considering environmental problems, do not directly lead to environmental action and, in some cases, can even obstruct the way to environmental activity. An insightful case study from Mali illustrates how religious interpretations of climate change do not encourage environmental protection endeavours but spiritual remedies (Bell 2014). Bell (2014) has conducted ethnographic research in the rural town of Ouélessébougou in Mali. Here, the environmental situation has significantly deteriorated over the last decades, affecting the living conditions of local populations. In their interpretation of environmental degradation and climate change, God appears as the manager of the climate. Bell identifies three predominant narratives why God changes the climate: (1) God undertakes natural shifts between different types of climate that people have to accept; (2) God's alteration of the local climate is a direct response to the immoral behaviour of local residents (e.g. stealing, lying); (3) with climate change, God is punishing humanity for its violent international conflicts and the selfish behaviour of global politicians. The three narratives regard God as managing the environmental conditions: local actors perceive climate change as God's will. For many local actors, it is God's reaction to people's immoral actions. Based on these interpretations, actors seek to deal with their environmental situation by appealing to God through rituals such as special prayer meetings asking God for rain. The study illustrates that their Islamic worldview shapes how these local actors understand and manage climate change. They do not attribute environmental degradation to the environmental attitudes and lifestyles of people, but to their social behaviour. Interestingly, this reading and dealing with climate change of rural Malian populations not only contradicts predominant scientific explanations, but also contrasts the approaches of leading Islamic environmental activities that try to improve environmental awareness and lifestyles of their Muslim peers. Though actors may regard climate change and environmental degradation through the lenses of their religious traditions, this does not imply that they undertake actions that are regarded by predominant scientific narratives as leading to an improved environmental situation. From the perspectives of these scientifically framed narratives about what climate change is, this study shows the limitations of religion to deal with environmental problems: if actors rely on ritual techniques to deal with climate change, they are unlikely to take up more environmentally friendly lifestyles in their daily routines. 
While the aforementioned studies mostly highlight the cognitive dimensions of faith - worldviews and ethics - and the potentials of Islamic organisations and leaders to reach local populations via communication, there are also physical projects. Studying the recycling activities of different faith communities in Malaysia, Mohamad et al. (2012) report a recycling program in more than 100 mosques in the State of Negeri Sembilan. Conducting case-study research on the Islamic community of Surau alHusna and communities from other faith backgrounds, they find that the recycling programs of religious communities create experimentation sites. These enable local actors for experimenting with innovative social practices - in this case: recycling - and disseminate these through their social networks to other communities. Contrasting other contributions which focus on the ability to spread worldviews and attitudes, this study highlights the practical abilities of religious communities, to establish and disseminate new environmentally friendly practices: religious communities can become experimentation sites to develop new, environmentally friendly techniques and practices. The dissemination of new environmentally friendly lifestyles is not solely undertaken by cognitive process, but by doing.

\subsubsection{Global North}

Studies from the Global South point in particular to the grassroots reach of Islamic engagement, highlighting the reputation of religious leaders, institutional resources of Muslim organisations, and their social networks. Still, the engagement appears to remain limited and it is, so far, not clear to what extent it affects the environmental attitudes of broader population segments. The Global North constitutes a different context where environmental awareness is usually believed to be higher. Therefore, one may assume broader activities among local Muslim communities. However, research from the UK contradicts this assumption.

Given the separation of environmental concern and lived Islam in the UK, Muslim environmental activists see the need to translate environmental concern into the language of Islam. A study of DeHanas (2009) illustrates this work of sacralising environmental concern and presenting it as Islamic. He studies the radio programme Women's Hour. The programme is a broadcast of the Muslim Community Radio in London's East End. During Ramadan 2007, the broadcaster placed an emphasis on environmental concerns. Analysing these broadcasts, DeHanas finds that they seek to place environmentalism into an Islamic narrative (DeHanas 2009:148-50): they sacralise the environmental discourse by embedding it within Islam. The radio hosts try to make appear environmental concern as genuinely Islamic. A prominent topic was recycling, as London's East End experiences problems with rubbish.

"The primary rhetorical strategy for motivating ecological actions was through tying them into habits of Islamic practice. In this way the Women's Hour broadcasting took many mainstream environmental activities, like recycling and water conservation, and imbued them with religious significance. It was a process of sacralizing environmentalism: extending the boundaries of the Islamic sacred and profane to subsume the categories of the environmental movement and grant them spiritual depth." (DeHanas 2009:148-49)

By placing an emphasis on Islamic environmental concern and the particular ecological issues in the district, the radio program sought to improve the public image of Islam in the UK (DeHanas 2009:15051). 
Gilliat-Ray and Bryant (2011) present a broader study about Islamic environmental activism in the UK. Exploring Islamic environmental engagement in the year 2010, they find a total of seven Islamic environmental groups, as well as a few cases of pioneering green mosques and Muslim urban gardening initiatives. Leaders of these initiatives usually diagnose a lack of environmental awareness among British Muslims. Therefore, they strive with their activities to improve knowledge about environmental problems and the importance of stewardship for God's Creation among British Muslims. The projects use social resources in the form of existing networks of Muslim communities. Moreover, they also use religious resources: paralleling the aforementioned radio broadcasts, they "sacralise" the environmental engagement. However, the activities do not reflect a general concern about environmental problems among British Muslims. The projects only involve small groups of environmentally concerned Muslim activists. Even within these very groups, Gilliat-Ray and Bryant find varying degrees of activity and dispersed membership. Islamic environmental groups have trouble to involve committed members and create durable activities. Thus, many of the groups studied have irregular meetings and show overall little activity.

"Many of the activists associated with British Muslim environmental issues and organisations have noted the obstacles that apathy, ignorance, and socio-economic deprivation pose to raising awareness of conservation among Muslims. The informal, often fragile and dispersed membership structure of Islamic environmental groups in Britain reflects these challenges." (Gilliat-Ray and Bryant 2011:299)

Despite these problems and the little general concern about environmental issues among British Muslims, Gilliat-Ray and Bryant optimistically see a rising engagement and potentials for lifestyle changes among British Muslims. They conclude: "These projects signal the potential for faith-based initiatives that go beyond merely informing or educating, and might lead to the possibility of real changes in behaviour" (Gilliat-Ray and Bryant 2011:303). The authors suppose that the rising engagement reflects an increased institutionalization of Islam in the UK, as Muslims become more interested in engaging with the broader society.

This optimism is not shared by a later study that underpins the marginalization of environmental topics in faith communities in the UK: Nita (2014) analyses Muslim environmental activists that are associated with the London Islamic Network for the Environment (later called: Wisdom in Nature). This group organized online networks, discussions, open forums, food sharing and gardening projects and diffused information via its monthly online leaflet (Nita 2014:230-32). However, the Muslim activists face a double marginalization: in their faith communities for being "green" and in their green communities for being religious (Nita 2014:233-35). Peers in their home mosque tend to regard their green engagement critically. At the same time, climate groups tend to marginalize religion and exclude religious actors from their rows. This double exclusion creates barriers for Islamic environmental engagement. To deal with this situation and continue their engagement, Muslim environmental activists evolve identity-merging strategies: they merge their religious and green identities and demarcate themselves from other "green" activists by attaching religious significance to their climate activism (Nita 2014:235-38). One particular mechanism for bringing their climate activism and religious identity together is the "green prayer". This ecological prayer combines the traditional form and rhythm with a new content: protest against climate change. According to Nita (2014), the prayer offers a unique opportunity for integrating this topic, given to its lament-celebration structure: it starts with lamentation and ends with celebrations. This structure allows for bringing in environmental concern and creating a fusion between the religious and environmental identity. This study illustrates 
the problems of Muslim environmental engagement. A climate movement dominated by actors that have critical perspectives on religion and scepticism against climate engagement among Muslim communities create a challenging context for Muslim climate activism. Against this backdrop, activists have to design creative strategies. Nevertheless, their religious tradition offers resources for solving this problem by filling the existing religious techniques (e.g. prayers, fasting) with new contents (e.g. protest against climate change). The study indicates that religions offer "vessels" that activists can use to fill with environmental concerns.

From the lenses of these studies conducted in the UK, environmental concern appears as something alien to Muslim communities that activists must integrate by using creative techniques. Though there is, so far, no strong concern, they point to the flexibility of religion and the potentials to integrate environmental concern into the existing structures of Islam in the UK (e.g. rituals, organisational structures, institutional leadership functions).

\section{Discussion}

This section compares the aforementioned studies, identifying the potentials and challenges of Muslim organisations in promoting environmental sustainability. Table 1 provides an overview of the studies.

Most of the activities mentioned in the studies are information-based: they seek to disseminate information (e.g. about Islamic environmental ethics) among Muslim communities. In some cases, the activities also involve practical projects such as recycling, planting trees, and improving the environmental standards in Islamic organisations.

The studies indicate that environmental concern is, so far, low among Muslim communities and not well integrated into the current lived practice of Islam. Therefore, pioneering actors and initiatives seek to spread environmental concern within lived Islam. They subscribe to an environmentally concerned, "green" Islam and disseminate it through workshops, books, radio broadcasts, school teachings, sermons, prayers, or sometimes practices (e.g. recycling). Dominant environmental topics in these campaigns seem to depend on the local context: for instance, in Indonesia, initiatives centred on logging, as deforestation puts Indonesia's ecological equilibrium in peril.

\begin{tabular}{|c|c|c|c|c|}
\hline Authors & Context & Case & Potentials & Challenges \\
\hline Rice 2006 & South & $\begin{array}{l}\text { High school teachers } \\
\text { and university } \\
\text { students in Cairo } \\
\text { (Egypt) }\end{array}$ & $\begin{array}{ll}\text { - } & \text { Islamic Environmental Ethics } \\
\text { - } & \text { Ability of Islam to promote } \\
\text { environmental concern } \\
\text { - } \quad \text { Grassroots reach: broader } \\
\text { population }\end{array}$ & - No information \\
\hline Sheikh 2006 & South & $\begin{array}{l}\text { Environmental } \\
\text { education project } \\
\text { involving religious } \\
\text { leaders in Pakistan }\end{array}$ & $\begin{array}{ll}\text { - } & \text { Reputation of religious leaders } \\
\text { - } & \text { Grassroots reach: access to } \\
& \text { rural communities }\end{array}$ & - No information \\
\hline $\begin{array}{l}\text { Mangunjaya } \\
\text { and McKay } \\
2012\end{array}$ & South & $\begin{array}{l}\text { Environmental } \\
\text { activities of Islamic } \\
\text { organisations and } \\
\text { leaders in Indonesia }\end{array}$ & $\begin{array}{ll}\text { - } & \text { Grassroots reach: local } \\
\text { communities } \\
\text { - } & \text { Practical project (e.g. } \\
& \text { reforestation) } \\
\text { - } & \text { Fatwas }\end{array}$ & $\begin{array}{l}\text { - Impact of } \\
\text { programmes } \\
\text { remains unclear }\end{array}$ \\
\hline Amri 2014 & South & $\begin{array}{l}\text { Environmental } \\
\text { activities of two } \\
\text { biggest Islamic }\end{array}$ & $\begin{array}{ll}\text { - } & \text { Islamic Environmental Ethics } \\
\text { - } & \text { Public impact } \\
\text { - } & \text { Grassroots reach } \\
\text { - } & \text { Organisational infrastructures }\end{array}$ & $\begin{array}{ll}- & \text { Elitism } \\
\text { - } & \text { Missing } \\
& \text { knowledge } \\
\text { - } & \text { Conflicting goals }\end{array}$ \\
\hline
\end{tabular}




\begin{tabular}{|c|c|c|c|c|}
\hline & & $\begin{array}{l}\text { organisations in } \\
\text { Indonesia }\end{array}$ & & \\
\hline Bell 2014 & South & $\begin{array}{l}\text { Religious explanations } \\
\text { of climate change in } \\
\text { rural town in Mali }\end{array}$ & $\begin{array}{l}\text { - Religion frames interpretations } \\
\text { of climate change }\end{array}$ & $\begin{array}{l}\text { Religious } \\
\text { interpretations } \\
\text { are not leading } \\
\text { to "green" } \\
\text { lifestyles }\end{array}$ \\
\hline $\begin{array}{l}\text { Mohamad } \\
\text { et al. } 2012\end{array}$ & South & $\begin{array}{l}\text { Recycling initiatives of } \\
\text { faith communities in } \\
\text { Malaysia }\end{array}$ & $\begin{array}{l}\text { - Experimentations sites for new } \\
\text { environmental practices }\end{array}$ & - No information \\
\hline $\begin{array}{l}\text { DeHanas } \\
2009\end{array}$ & North & $\begin{array}{l}\text { Environmental focus } \\
\text { of Islamic radio } \\
\text { programme during } \\
\text { Ramadan } 2007 \text { in } \\
\text { Londons' East End }\end{array}$ & $\begin{array}{l}\text { - Islamic Environmental Ethics } \\
\text { - } \text { Ability to integrate } \\
\text { environmental concern in lived } \\
\text { Islam }\end{array}$ & $\begin{array}{l}\text { Existing } \\
\text { separation } \\
\text { between lived } \\
\text { Islam and } \\
\text { environmental } \\
\text { concern } \\
\end{array}$ \\
\hline $\begin{array}{l}\text { Gilliat-Ray } \\
\text { and Bryant } \\
2011\end{array}$ & North & $\begin{array}{l}\text { Islamic environmental } \\
\text { activism in UK }\end{array}$ & $\begin{array}{ll}\text { - } & \text { Islamic Environmental Ethics } \\
\text { - } & \text { Grassroots reach: use of social } \\
\text { networks } \\
\text { - }\end{array}$ & $\begin{array}{l}\text { - } \text { Low } \\
\text { commitment } \\
\text { - } \text { Dispersed } \\
\text { membership in } \\
\text { initiatives }\end{array}$ \\
\hline Nita 2014 & North & $\begin{array}{l}\text { Muslim environmental } \\
\text { activists relating with } \\
\text { faith communities and } \\
\text { climate movement in } \\
\text { UK }\end{array}$ & $\begin{array}{l}\text { - Ability to integrate } \\
\text { environmental concern in } \\
\text { Islam (e.g. prayers) }\end{array}$ & $\begin{array}{l}\text { - } \text { Critical } \\
\text { reception in } \\
\text { religious } \\
\text { communities }\end{array}$ \\
\hline
\end{tabular}

Table 1: Potentials and Challenges of Islamic Environmental Engagement

The studies suggest various potentials of Islam for promoting environmental concern. Studies mostly highlight the environmental ethics of Islam and its grassroots reach. Stressing the environmental teachings of Islam, they underpin the possibility of integrating environmental concern and ethics within lived practice of Islam. As Islam structures the perceptions and actions of many Muslims, "rediscovering" the environmental ethics of Islam (Foltz 2000; Saniotis 2012) becomes a powerful source for establishing more environmentally sustainable lifestyles, economics, and politics in Muslim majority countries. To this end, grassroots reach also constitutes a key asset, as it allows for accessing broader populations. In particular, in Global South countries, the communication of Islamic leaders and organisations is likely to have a broader and stronger grassroots reach than secular institutions (Mangunjaya and McKay 2012; Rice 2006). The presence of religious actors on the grassroots levels converts them into valuable access points and multipliers for stretching out to local communities. In particular, the credibility of religious leaders (Sheikh 2006) facilitates the communication with local populations. In many occasions, local religious leaders even become gatekeepers that influence what information the given local population regards as credible. In addition, the organisational structures of Islamic organisations can facilitate the contact with local populations: This can be undertaken by using Islamic radio broadcaster such as Muslim Community Radio in London's East End (DeHanas 2009). Another example are the Islamic organisations Muhammadiyah and Nahdlatul Ulama in Indonesia that seek to encourage the teaching of environmental ethics in their local schools and mosques (Amri 2014). In addition, Islamic organisations can use their infrastructures and financial resources to undertake practical environmental projects (e.g. reforestation) (Mangunjaya and McKay 2012). In the context of such projects, local religious communities can learn new environmentally techniques (e.g. recycling) through experimentation (Mohamad et al. 2012). Finally, Islam may provide interpretation frames for understanding environmental degradation (Bell 2014). 
However, religious interpretation frames do not necessarily lead to environmentally friendly behaviour and may even inhibit environmental action, as the study of Bell (2014) shows. Other problems of Islamic environmental engagement concern its supposed elitism and the low environmental interest among broader population segments. The studies indicate that environmental concern has mostly remained alien to current Muslim communities. Therefore, in the aforementioned initiatives, Islam and its organisational structures become vehicles for transporting environmental concern to local populations. Yet, employing Islam as a vehicle might incite accusations of instrumentalising religion and create acceptance problems among religious leaders and followers (see also Petersen 2012a:137). Some of the studies indicate problems in the dissemination of environmental concern. For instance, Amri (2014:87) mentions difficulties in implementing environmental mandates within Muhammadiyah's schools and universities, as environmental goals compete with other goals in this organisation: environmental sustainability does not assume the priority, given that organisations perceives other issues - such as poverty alleviation, education, and health - as more relevant in the context of the Global South. In addition, Amri (2014) signals that environmental engagement appears to remain elitist. Finally, the broader impact of these initiatives remains unclear: it is uncertain whether the targeted Muslim communities are becoming "greener" over time (Mangunjaya and McKay 2012). Moreover, the studies indicate that only a minority of Muslims actively engage in these efforts of "greening" Islam and Muslim communities (Amri 2014; Gilliat-Ray and Bryant 2011). Research from the UK suggests that Islamic environmental groups face difficulties to maintain their membership and activities over time (Gilliat-Ray and Bryant 2011) and Islamic environmental activists even suffer low acceptance in their faith communities (Nita 2014). In addition, Nita (2014:233-35) observes that the climate change movement marginalizes religion and tries to exclude religious activist from its rows.

\section{Conclusion}

Against the backdrop of a novel emphasis on environmental sustainability in the international development agenda, this contribution has addressed the potential resources and problems of Muslim NGOs in promoting environmental sustainability.

The religion and ecology debate highlights the capacities of religious organisations in addressing environmental problems and facilitating social transformations towards more environmentally friendly societies. While most studies have focused on Christian organisations, there are comparatively little studies on Islamic environmental engagement. Therefore, this contribution has analysed and compared empirical studies on Islamic environmental initiatives to determine the potentials and problems of Muslim NGOs in environmental sustainability.

Many studies stressed the environmental teachings of Islam and its grassroots reach as crucial resources: their credibility and presence in local places enables them to disseminate Islamic environmental ethics and thereby to potentially alter the environmental attitudes of broad population segments in the Global South. Moreover, the organisational infrastructure and material resources of Muslim organisations enable them to undertake physical projects (e.g. reforestation), allowing followers to experimenting with new environmental practices.

However, the impact of environmental activism on broader populations remains, so far, unclear. In addition, to what extent the aforementioned features in fact become resources for promoting environmental sustainability cannot be generalized. This will depend, inter alia, on the profile of the 
given organisations and the socio-geographical context in which they engage. In many contexts, in the Global South, the grassroots reach depends on the perceived Islamic identity of the given organisation. Yet, international development agencies and governments regard religion only as an unloved but helpful instrument, while, at the same time, seeking to minimize the "religious" features of religious development work. A minimized religious identity will affect the pursued grassroots reach, as "secular" Muslim NGOs frequently suffer from lower credibility among local populations (Cordier 2009; Palmer 2011; Petersen 2012b:775). A strictly instrumental approach to religion might therefore turn out to be counterproductive.

To improve our knowledge about the resources, limitations, and their regional embeddedness, there is need for further research about Islamic environmental activism and its impacts in different sociogeographical contexts. In particular, comparative research might help to identify what resources and limitations are relevant in which contexts. Apart from qualitative case-study research, quantitative research could study how international Muslim NGOs relate to the SDGs, exploring the development profiles of these organisations. This research could analyse what development goals religious NGOs prioritize and what role environmental sustainability assumes among these actors. By providing indepth knowledge about the SDGs' priorities and ecological involvement of religious NGOs, research could help to solve the question of to what extent and in what way environmental sustainability plays a role in $21^{\text {st }}$ century religious development work.

\section{References}

Ahmed, Chanfi. 2009. "Networks of Islamic NGOs in sub-Saharan Africa: Bilal Muslim Mission, African Muslim Agency (Direct Aid), and al-Haramayn." Journal of Eastern African Studies 3(3):426-37. doi:10.1080/17531050903273727.

Amri, Ulil. 2014. "From Theology to a Praxis of "Eco-Jihad": The Role of Religious Civil Society Organizations in Combating Climate Change in Indonesia." Pp. 75-93, In How the World's Religions Are Responding to Climate Change: Social Scientific Investigations, edited by R. G. Veldman, A. Szasz, and R. Haluza-DeLay. $1^{\text {st }}$ ed. London: Routledge.

Beinlich, Ann-Kristin, and Clara Braungart. 2019. "Religions NGOs at the UN: A quantitative overview." Pp. 26-46 in Routledge studies in religion and politics, Religious NGOs at the United Nations: Polarizers or mediators?, edited by C. Baumgart-Ochse and K. D. Wolf. Abingdon, Oxon, New York, NY: Routledge.

Bell, Dianna. 2014. "Understanding a 'Broken World': Islam, Ritual, and Climate Change in Mali, West Africa." Journal for the Study of Religion, Nature \& Culture 8(3):287-306. doi:10.1558/jsrnc.v8i3.287.

Clugston, Richard, and Steve Holt, editors. 2012. Exploring Synergies Between Faith Values and Education for Sustainable Development. San José: Earth Charter International.

Cordier, Bruno de. 2009. "Faith-Based Aid, Globalisation and the Humanitarian Frontline: An Analysis of Western-Based Muslim Aid Organisations." Disasters 33(4):608-28. doi:10.1111/j.1467-

7717.2008.01090.x.

DeHanas, Daniel N. 2009. "Broadcasting Green: Grassroots Environmentalism on Muslim Women's Radio." The Sociological Review 57(2_suppl):141-55. doi:10.1111/j.1467-954X.2010.01890.x.

Foltz, Richard. 2000. “Is There an Islamic Environmentalism?” Environmental Ethics 22(1):63-72. doi:10.5840/enviroethics200022149. 
Gardner, Gary T. 2003. "Engaging Religion in the Quest for a Sustainable World." Pp. 152-75, In State of the World, 2003: A Worldwatch Institute Report on Progress Toward a Sustainable Society, edited by Worldwatch Institute. New York: W. W. Norton \& Company.

Gilliat-Ray, Sophie, and Mark Bryant. 2011. "Are British Muslims 'Green'?: An Overview of Environmental Activism among Muslims in Britain." Journal for the Study of Religion, Nature \& Culture 5(3):284-306. doi:10.1558/jsrnc.v5i3.284.

Glaab, Katharina. 2017. "A Climate for Justice?: Faith-based Advocacy on Climate Change at the United Nations." Globalizations 13(4):1-15. doi:10.1080/14747731.2017.1308060.

Gottlieb, Roger. 2008. "You Gonna Be Here Long? Religion and Sustainability." Worldviews: Global Religions, Culture, and Ecology 12(2):163-78. doi:10.1163/156853508X359967.

Kaag, Mayke. 2007. “Aid, Umma, and Politics: Transnational Islamic NGOs in Chad." Pp. 85-102, in Islam and Muslim politics in Africa, edited by B. Soares and R. Otayek: Springer.

Kanagy, Conrad L., and Fern K. Willits. 1993. "A "Greening" of Religion? Some Evidence from a Pennsylvania Sample." Social Science Quarterly 74(3):674-83.

Kimmins, J. P. 1993. "Ecology, environmentalism and green religion." The Forestry Chronicle 69(3):285-89. doi:10.5558/tfc69285-3.

Kirmani, N., and A. A. Khan. 2008. "Does Faith Matter: An Examination of Islamic Relief's Work with Refugees and Internally Displaced Persons." Refugee Survey Quarterly 27(2):41-50. doi:10.1093/rsq/hdn032.

Koehrsen, Jens. 2015. "Does Religion Promote Environmental Sustainability? - Exploring the Role of Religion in Local Energy Transitions." Social Compass 62(3):296-310. doi:10.1177/0037768615587808.

Koehrsen, Jens. 2018. "Religious Agency in Sustainability Transitions: Between Experimentation, Upscaling, and Regime Support." Environmental Innovation and Societal Transitions 27:4-15. doi:10.1016/j.eist.2017.09.003.

Mangunjaya, Fachruddin M., and Jeanne E. McKay. 2012. "Reviving an Islamic approach for environmental conservation in Indonesia." Worldviews: Global Religions, Culture, and Ecology 16(3):286-305.

Mohamad, Zeeda F., Noorshahzila Idris, and Zuffri Mamat. 2012. "Role of Religious Communities in Enhancing Transition Experiments: A Localised Strategy for Sustainable Solid Waste Management in Malaysia." Sustainability Science 7(2):237-51. doi:10.1007/s11625-012-0169-1.

Nita, Maria. 2014. "Christian and Muslim Climate Activists Fasting and Praying for the Planet: Emotional Translation of "Dark Green" Activism and Green-Faith Identities." Pp. 229-43, In How the World's Religions Are Responding to Climate Change: Social Scientific Investigations, edited by R. G. Veldman, A. Szasz, and R. Haluza-DeLay. $1^{\text {st }}$ ed. London: Routledge.

Palmer, Victoria. 2011. "Analysing cultural proximity: Islamic Relief Worldwide and Rohingya refugees in Bangladesh." Development in Practice 21(1):96-108. doi:10.1080/09614524.2011.530226.

Petersen, Marie J. 2012a. "Islamizing Aid: Transnational Muslim NGOs after 9.11." Voluntas: International Journal of Voluntary and Nonprofit Organizations 23(1):126-55.

Petersen, Marie J. 2012b. "Trajectories of transnational Muslim NGOs." Development in Practice 22(5-6):763-78. doi:10.1080/09614524.2012.685876.

Rasmussen, Larry L. 2011. "Energy: the Challenges to and from Religion." Zygon 46(4):985-1002. doi:10.1111/j.1467-9744.2011.01224.x.

Rice, Gillian. 2006. "Pro-environmental behavior in Egypt: Is there a role for Islamic environmental ethics?" Journal of Business Ethics 65(4):373-90. 
Rolston III, Homes. 2006. "Science and Religion in the Face of the Environmental Crisis." Pp. 376-97, In The Oxford Handbook of Religion and Ecology, edited by R. S. Gottlieb: Oxford University Press. Salih, Mohamed A. R. M. 2002. Islamic NGOs in Africa: The promise and peril of Islamic voluntarism: Citeseer.

Saniotis, Arthur. 2012. "Muslims and ecology: Fostering Islamic environmental ethics." Contemporary Islam 6(2):155-71.

Sheikh, Kashif M. 2006. "Involving Religious Leaders in Conservation Education in the Western Karakorum, Pakistan." Mountain Research and Development 26(4):319-22. doi:10.1659/02764741(2006)26[319:IRLICE]2.0.CO;2.

Shibley, Mark A., and Jonathon L. Wiggins. 1997. "The Greening of Mainline American Religion: a Sociological Analysis of the Environmental Ethics of the National Religious Partnership for the Environment." Social Compass 44(3):333-48. doi:10.1177/003776897044003003.

Taylor, Bron. 2010. Dark Green Religion: Nature Spirituality and the Planetary Future: Univ of California Press.

Taylor, Bron, Gretel van Wieren, and Bernard D. Zaleha. 2016. "Lynn White Jr. and the Greening-ofReligion Hypothesis." Conservation Biology 30(5):1000-09. doi:10.1111/cobi.12735.

Tucker, Mary E. 2006. "Religion and Ecology: Survey of the Field." Pp. 398-418, In The Oxford Handbook of Religion and Ecology, edited by R. S. Gottlieb: Oxford University Press.

Tucker, Mary E. 2008. "World Religions, the Earth Charter, and Sustainability." Worldviews: Global Religions, Culture, and Ecology 12(2):115-28. doi:10.1163/156853508X359930.

White, Lynn. 1966. "The Historical Roots of Our Ecologic Crisis." Science 155(3767):1203-07. doi:10.1126/science.155.3767.1203. 